\title{
PROPORSI DAN KADAR PROKSIMAT BAGIAN TUBUH IKAN TUNA EKOR KUNING (Thunnus albacares) DARI PERAIRAN MALUKU
}

\section{PROPORTION AND PROXIMATE ANAL YSIS PARTS OF BODY YELLOWFIN TUNA (Thunnus albacares) FROM MALUKU}

\author{
Sugeng Hadinoto dan Syarifuddin Idrus \\ Balai Riset dan Standardisasi Industri Ambon \\ Jl. Kebun Cengkeh Ambon \\ email : sugenghadin15@gmail.com
}

Received : 22/09/2018; revised : 14/12/2018; accepted : 20/12/2018

Published online : $31 / 12 / 2018$

\begin{abstract}
ABSTRAK
Setiap perkembangan industri pengolahan perikanan, termasuk pengolahan ikan tuna pasti akan menyisakan hasil samping berupa kulit, kepala, tulang ataupun isi perut ikan. Hasil samping tersebut tersebut dapat dimanfaatkan menjadi produk lain yang bernilai. Penelitian ini bertujuan untuk mengkaji jumlah proporsi bagian tubuh ikan tuna dan mengetahui kandungan gizi pada daging, telur, kulit dan gelembung renang ikan tuna ekor kuning. Penelitian ini dilakukan dalam tiga tahap, yaitu pengambilan sampel dipasar tradisional Mardika Ambon; preparasi dan mengukuran berat bagian tubuh ikan tuna; analisis proksimat bagian tubuh ikan tuna. Data yang diperoleh dianalisis secara deskriptif. Proporsi bagian tubuh ikan dari berat total ikan tuna $20 \mathrm{~kg}$, yaitu daging 59\%; kepala 17,5\%; kulit 3,25\%; tulang 13,75\%; jeroan 6,07\% dan gelembung renang 0,43\%. Pengukuran kadar proksimat terhadap bagian tubuh ikan tuna diperoeh hasil: kadar air (daging 71,73\%, telur 72,02\%, kulit 59,31\%, gelembung renang 79,74\%); kadar abu (daging 1,48\%, telur 1,46\%, kulit 5,73\%, gelembung renang 0,81\%); kadar protein (daging $28,34 \%$, telur 22,83\%, kulit 37,32\%, gelembung renang $17,52 \%$ ); kadar lemak (daging $0,51 \%$, telur $0,63 \%$, kulit $9,17 \%$, gelembung renang $1,64 \%$ ). Dari penelitian yang telah dilakukan diperoleh kesimpulan bahwa selain daging, bagian tubuh ikan tuna yang lain juga memiliki potensi gizi yang baik, kulit ikan tuna mengandung protein yang lebih banyak dibandingkan dengan daging.
\end{abstract}

Kata kunci : ikan tuna ekor kuning (Thunnus albacares), proksimat, daging, gelembung renang

\begin{abstract}
Any development of the fishery processing industry, including the processing of tuna will definitely leave the side of skin, head, bone or viscera. These byproducts can be utilized to be another valuable product. This study aims to assess the proportion of tuna and to know the nutritional content of meat, eggs, skin and swimbladder yellowfin tuna. This research was conducted in three stages: sampling in traditional market of Mardika Ambon; preparation and weight measurement of tuna body parts; proximate analysis of tuna body parts. The data obtained were analyzed descriptively. The proportion of fish body parts from the total weight of tuna $20 \mathrm{~kg}$; meat 59\%; head 17.5\%; skin 3.25\% ; bone 13.75\%; viscera $6.07 \%$ and swimbladder $0.43 \%$. Measurement of proximate content on the tuna body parts resulted in: moisture content (meat $71.73 \%$, eggs $72.02 \%$, skin $59.31 \%$, swimbladder $79.74 \%$ ); ash content (meat 1.48\%, eggs $1.46 \%$, skin $5.73 \%$, swimbladder $0.81 \%$ ); protein content (meat 28,34\%, eggs 22,83\%, skin 37,32\%, swimbladder $17,52 \%$ ); fat content (meat $0.51 \%$, eggs $0.63 \%$, skin $9.17 \%$, swimbladder $1.64 \%$. From the research that has been done to obtain the conclusion that in addition to meat, other tuna body parts also have good nutritional potential, tuna skin contains more protein than meat.
\end{abstract}

Keywords : yellowfin tuna (Thunnus albacares), proximate, meat, swimmbladder

\section{PENDAHULUAN}

Salah satu hasil perikanan tangkap yang potensial di perairan Maluku adalah ikan tuna sirip kuning (Thunus albacares). Menurut data perikanan tangkap di Maluku, hasil tangkapan ikan tuna pada tahun 2016 sebesar 14.363,1 ton dengan hasil produksi terbesar terdapat pada Kabupaten Maluku Tengah sebesar 6.940,1 ton. Nilai ini mengalami penurunan jika dibandingkan hasil produksi pada tahun 2015 yaitu sebesar 19.217,6 ton.

Ikan tuna adalah jenis ikan dengan kandungan protein yang tinggi dan lemak yang rendah. Ikan tuna mengandung protein antara 22,6 - 26,2 g/100 g daging, lemak antara 0,2 $2,7 \mathrm{~g} / 100 \mathrm{~g}$ daging. Ikan tuna mengandung mineral (kalsium, fosfor, besi, sodium), vitamin A (retinol), dan vitamin B (thiamin, riboflavin, dan niasin) (Stansby dan Olcott, 1963). 
Setiap perkembangan industri pengolahan perikanan, termasuk pengolahan ikan tuna pasti akan menyisakan hasil samping berupa kulit, kepala, tulang ataupun isi perut ikan. Hasil samping tersebut sering dibuang begitu saja, padahal hasil samping tersebut dapat dimanfaatkan menjadi produk yang bernilai. Pemanfaatan limbah ini merupakan penerapan dari salah satu prinsip ekonomi biru (blue economy) yang saat ini sedang gencar dikembangkan, yaitu prinsip nirlimbah (zero waste) yang menekankan sistem siklikal dalam proses produksi, sehingga tercipta produksi bersih.

Limbah merupakan hasil sampingan proses pengolahan dan atau sisa bahan baku dengan kualitas sangat rendah, dan apabila tidak ditangani secara baik dan atau dimanfaatkan sebagai bahan produk turunan akan menimbulkan pencemaran lingkungan. Limbah yang dihasilkan oleh industri perikanan berkisar antara 25-30\% yakni sekitar 3,6 juta ton per tahun (KKP, 2007). Limbah padat yang dihasilkan dari industri pengolahan tuna dapat berupa sisa potongan daging (leresan), kulit, kepala, jeroan, tulang, sisik dan sirip. Pengolahan fillet tuna menghasilkan 30-40\% limbah dari total berat bersih sehingga dapat dikatakan bahwa $60-70 \%$ dari tubuh ikan merupakan limbah yang tidak dimanfaatkan (Silva et al., 2010). Lemak yang terkandung pada jeroan dan kulit ikan dapat menyebabnbykan penurunan kualitas air jika langsung dibuang ke perairan. Tuna dengan berat antara 75-90 kg menurut Sahubawa (2012) dapat menghasilkan sebesar 5 kilogram jeroan. Penerapan konsep zero waste untuk meminimalisir limbah yang dihasilkan penting dilaksanakan untuk mengurangi dampak limbah tersebut bagi lingkungan. Penelitian tentang pemanfaatan daging maupun hasil samping produksi ikan tuna, antara lain yang dilakukan oleh Abun et al. (2004) tentang uji coba pemanfaatan limbah ikan tuna telah dilakukan dan digunakan secara komersial sebagai silase ikan, tepung tulang (Trilaksani et al., 2006), biodiesel dari jeroan ikan tuna (Fauzi, 2014), gelatin atau kolagen dari kulit ikan tuna (Pangke et al., 2016), kolagen dari gelembung renang ikan tuna (Kaewdang et al., 2014).

Penelitian ini bertujuan untuk mengkaji jumlah proporsi bagian tubuh ikan tuna dan mengetahui kandungan gizi pada daging, telur, kulit dan gelembung renang ikan tuna.

\section{METODE PENELITIAN}

\section{Bahan dan Alat}

Bahan yang digunakan yaitu bagian tubuh ikan Tuna (Thunnus albacares) berupa daging, telur, kulit dan gelembung renang, sedangkan bahan kimia yang digunakan antara lain aquabides, $\mathrm{K}_{2} \mathrm{SO}_{4}, \mathrm{HgO}, \mathrm{H}_{2} \mathrm{SO}_{4}$ pekat, $\mathrm{H}_{3} \mathrm{BO}_{3}$, $\mathrm{NaOH}, \mathrm{HCl}$. Alat yang digunakan pada penelitian ini yaitu oven, kjeltec, alat ekstraksi sokhlet, kertas saring, neraca analitik, tabung reaksi, gelas beaker, cawan porselin, desikator, tanur.

\section{Metode Penelitian}

Penelitian ini dilakukan dalam tiga tahap, yaitu pengambilan sampel; preparasi dan mengukuran berat bagian tubuh ikan tuna; analisis proksimat bagian tubuh ikan tuna. Sampel ikan tuna merupakan hasil tangkapan nelayan dari perairan Maluku yang diperoleh di Pasar Tradisional Mardika Ambon. Data yang diperoleh dianalisis secara deskriptif.

\section{Parameter Uji}

Pengukuran kandungan gizi pada daging, telur, kulit dan gelembung renang ikan tuna meliputi analisis kadar air, kadar abu, kadar protein, dan kadar lemak (AOAC, 2005).

\section{HASIL DAN PEMBAHASAN}

\section{Berat dan Persentase Bagian Tubuh Ikan Tuna}

Ikan yang menjadi objek penelitian adalah ikan tuna ekor kuning (Thunnus albacares) yang diperoleh di Pasar Tradisional Mardika Ambon. Berat ikan yang diteliti mencapai $20 \mathrm{~kg}$ atau 20000 gram. Ikan tuna yang dijadikan sampel belum masuk dalam fase bertelur, sampel telur ikan diperoleh dari pedagang ikan yang khusus menjual telur ikan tuna. Setelah ikan dipreparasi, diperoleh bagian-bagian utama pada ikan seperti kepala, tulang, daging, kulit, jeroan, dan gelembung renang. Persentase bagian-bagian tubuh ikan tuna hasil preparasi dapat dilihat pada Tabel 1.

Tabel 1 menunjukkan bahwa ikan tuna terdiri dari daging atau bagian yang bisa dikonsumsi sebesar $59 \%$ dari total berat tubuh ikan, daging ikan tuna yang diukur adalah daging merah maupun daging putih. Pengukuran selanjutnya adalah bagian kepala, berat kepala ikan tuna mencapai $17,5 \%$.

Tabel 1. Berat dan Persentase Bagian Tubuh Ikan Tuna (Thunnus albacares)

\begin{tabular}{lcc}
\hline \multirow{2}{*}{$\begin{array}{c}\text { Bagian } \\
\text { tubuh }\end{array}$} & \multicolumn{2}{c}{ Ikan Tuna (Thunnus albacares) } \\
\cline { 2 - 3 } & Berat (g) & Persentase (\%) \\
\hline Daging & 11800 & 59,00 \\
Kulit & 650 & 3,25 \\
Kepala & 3500 & 17,50 \\
Tulang & 2750 & 13,75 \\
Jeroan & 1214 & 6,07 \\
Gelembung & 86 & 0,43 \\
renang & & \\
\hline
\end{tabular}


Bagian kepala yang diukur termasuk tulang kepala, bibir dan rahang, insang, penutup insang, mata, otak dan sisa daging yang terdapat pada bagian kepala. Pada pengukuran tulang diperoleh hasil sebesar 13,75\%, pengukuran tulang meliputi seluruh ruas tulang belakang dari pertemuan tulang kepala sampai tulang ekor, sirip ekor, sirip dada, sirip anal dan sirip punggung. Hasil pengukuran kulit, jeroan (termasuk darah) dan gelembung renang ikan tuna diperoleh hasil masing-masing berurutan $3,25 \%, 6,07 \%$, dan $0,43 \%$.

Menurut Stansby dan Olcott (1963), ikan tuna terdiri dari $50-60 \%$ bagian tubuh yang bisa dikonsumsi. Pengolahan fillet tuna menghasilkan 30-40\% limbah dari total berat bersih sehingga dapat dikatakan bahwa 60-70\% dari tubuh ikan merupakan limbah yang tidak dimanfaatkan (Silva et al., 2010). Sahubawa (2012) mengungkapkan bahwa ikan tuna dengan berat antara 75-90 kg dapat menghasilkan sebesar 5 kilogram jeroan.

\section{Kandungan Gizi Bagian Tubuh Ikan Tuna}

Gizi merupakan ikatan kimia yang dibutuhkan oleh tubuh untuk melakukan fungsinya menghasilkan energi, membangun, memelihara, dan memperbaiki jaringan (Sudarmadji et al., 2007). Zat gizi diklasifikasikan menjadi 6 kelompok besar yaitu karbohidrat, protein, lemak, vitamin, mineral dan air (Tejasari, 2005).

Kandungan gizi ikan tuna bervariasi tergantung spesies, jenis, umur, musim, laju metabolisme, aktivitas pergerakan, musim dan tingkat kematangan gonad (Wahyuni 2011). Demikian juga pada tiap bagian tubuh ikan tuna seperti pada daging dan kulit mengandung nilai gizi yang berbeda.

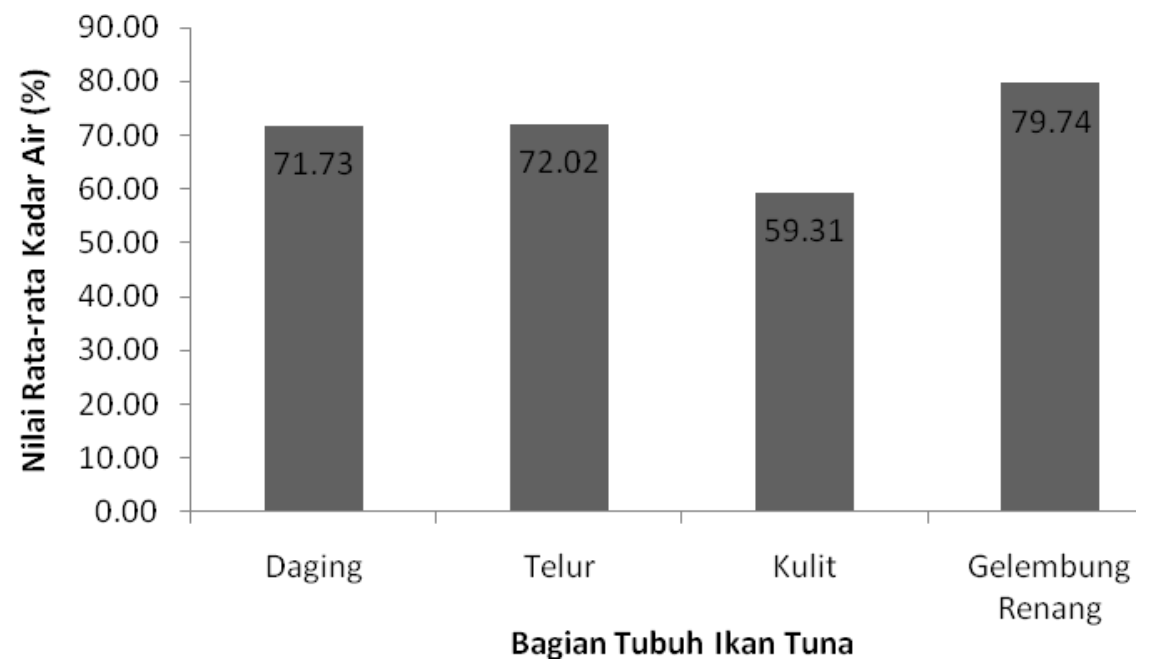

Gambar 1. Nilai Rata-Rata Kadar Air pada Bagian Tubuh Ikan Tuna

\section{Kadar Air}

Kadar air merupakan banyaknya air yang terkandung dalam bahan yang sangat dibutuhkan untuk proses pencernaan dan metabolisme. Hasil pengukuran kadar air pada bagian tubuh ikan tuna dapat dilihat pada Gambar 1.

Daging ikan laut mengandung air sekitar $50-85 \%$ tergantung pada spesies dan status gizi dari ikan tersebut. Ikan dalam keadaan lapar atau pada saat sedang bertelur akan kehilangan simpanan energi pada jaringan sehingga meningkatkan kadar air daging (Irianto dan Giyatmi, 2009).

Kadar air pada daging ikan tuna $71,73 \%$, nilai ini lebih rendah dibandingkan daging ikan tuna yang diteliti oeh Wahyuni (2011) yaitu $74,00 \%$, tetapi lebih tinggi dibandingkan hasil penelitian Wellyalina (2013) $56,43 \%$. Telur ikan tuna mengandung kadar air $72,02 \%$, lebih tinggi dibandingkan dengan kadar air telur ikan cakalang 71,32\% (Rieuwpassa et al, 2013) dan telur ikan terbang 17,39\% (Azka et al, 2015).

Kulit ikan tuna mengandung kadar air $59,31 \%$, nilai ini tidak berbeda jauh dengan hasil penelitian Nurilmala et al, (2017) dan Hema et a, (2013) yaitu 59,38\% dan 56,54\%. Kadar air pada gelembung renang ikan tuna $79,74 \%$, Nilai tersebut lebih tinggi dari kandungan air gelembung renang ikan ikan tuna ekor kuning (Thunnus albacares) yang diteliti oleh Kaewdang et al. (2014) 73,03\%, sedangkan gelembung renang ikan cunang yang diteliti oleh Gadi et al (2017) mengandung kadar air $65,00 \%$.

Kadar air dalam bahan makanan sangat mempengaruhi kualitas dan daya simpan dari pangan tersebut. Oleh karena itu, penentuan kadar air dari suatu bahan pangan sangat penting agar dalam proses pengolahan maupun pendistribusian mendapat penanganan yang 
tepat. Bahan pangan dengan kadar air yang tinggi apabila tidak ditangani dengan benar akan cepat mengalami kemunduran mutu oleh aktivitas bakteri dan enzim (llyas, 1983).

\section{Kadar Abu}

Abu adalah zat anorganik sisa hasil pembakaran suatu bahan organik. Kadar abu menunjukkan kadar mineral yang terdapat dalam suatu bahan. Proses metabolisme berperan dalam pembentukan mineral tubuh. Pengabuan dilakukan untuk menentukan jumlah mineral yang terkandung dalam bahan.

Penentuan kadar mineral bahan secara asli sangatlah sulit sehingga perlu dilakukan dengan menentukan sisa hasil pembakaran atas garam mineral bahan tersebut. Pengabuan dapat menyebabkan hilangnya bahan-bahan organik dan anorganik sehingga terjadi perubahan radikal organik dan terbentuk elemen logam dalam bentuk oksida atau bersenyawa dengan ion-ion negatif (Sudarmadji et al., 2007). Hasil pengukuran kadar abu pada bagian tubuh ikan tuna dapat dilihat pada Gambar 2.

Gambar 2 menunjukkan nilai rata-rata kadar abu pada bagian tubuh ikan tuna berurutan, yaitu pada daging $1,48 \%$, telur $1,46 \%$, pada kulit $5,73 \%$ dan $0,81 \%$ pada gelembung renang. Pada gambar 2 dapat dilihat bahwa nilai kadar abu tertinggi terdapat pada bagian kulit ikan tuna yaitu sebesar $5,73 \%$ dan terendah pada gelembung renang sebesar $0,81 \%$. Tinggi rendahnya kadar abu suatu bahan pangan tergantung pada kemampuan bahan pangan tersebut meregulasi dan mengabsorbsi logam (Winarno, 2008).

Wahyu et al (2013) menyatakan bahwa kadar abu yang terkandung dalam tubuh ikan dipengaruhi oleh jenis makanan dan kandungan mineral yang terdapat pada habitat hidup ikan tersebut.

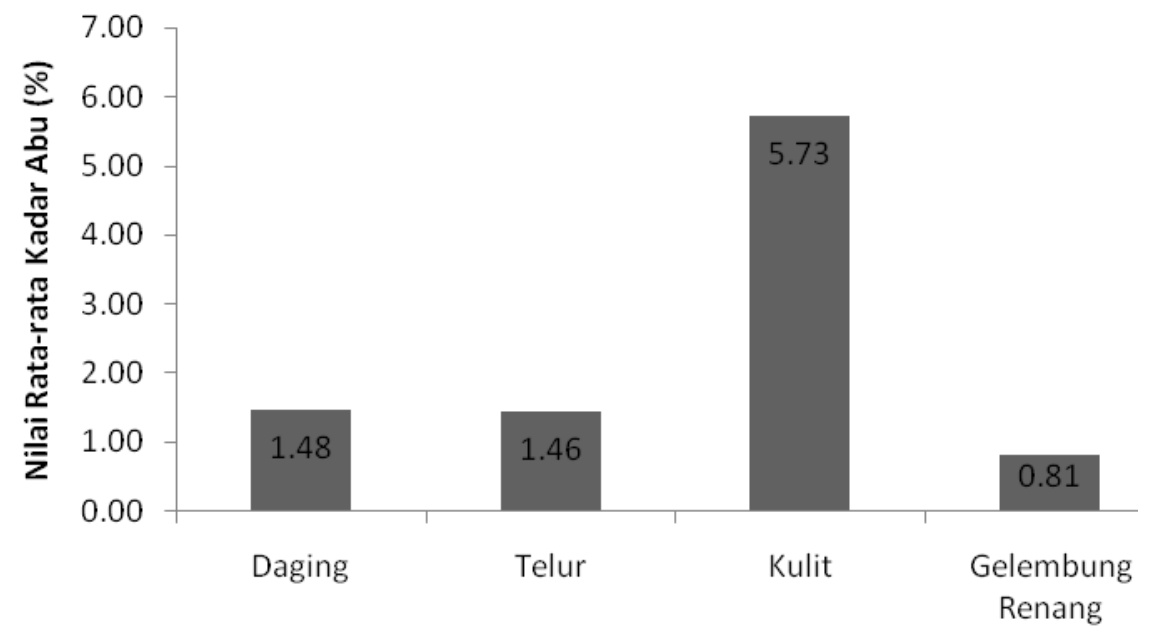

Bagian Tubuh Ikan Tuna

Gambar 2. Nilai Rata-Rata Kadar Abu pada Bagian Tubuh Ikan Tuna

Daging ikan tuna mengandung kadar abu sebesar $1,48 \%$. Hasil penelitian Wahyuni (2011) dan Wellyalina (2013) menunjukkan hasil yang lebih rendah, yaitu $1,3 \%$ dan $1,01 \%$.

Kadar abu pada telur ikan tuna sebesar $1,46 \%$ sedangkan pada telur ikan cakalang mencapai 2,04\% (Rieuwpassa et al, 2013) dan $6,62 \%$ pada telur ikan terbang (Azka et al, 2015).

Kulit ikan tuna mengandung kadar abu $5,73 \%$, nilai ini lebih tinggi jika dibandingkan dengan hasil penelitian Nurilmala et al, (2017) dan Hema et a, (2013) yaitu 2,21\% dan 4,39\%. Kadar abu pada gelembung renang ikan tuna $0,81 \%$, nilai ini lebih tinggi jika dibandingkan dengan hasil penelitian Kaewdang et al, (2014) yaitu $0,29 \%$, kadar abu pada gelembung renang ikan cunang 0,17\% (Gadi et al., 2017).

\section{Kadar Protein}

Protein dalam tubuh ikan merupakan senyawa yang kandungannya paling tinggi setelah air. Protein memegang peranan penting dalam struktur dan fungsi tubuh, seperti pertumbuhan dan reproduksi. Pada ikan, tidak hanya protoplasma pada sel hidup saja yang terdiri dari protein tetapi juga nukleusnya yang mengawasi aktivitas dari sel, yakni protein. Oleh karena itu, protein merupakan bagian terbesar dari urat daging, alat-alat tubuh dan tulang (Sugiono, 2007). Protein mengandung rantai asam amino yang sangat penting, terutama untuk fungsi pertumbuhan (anabolisme) dan fungsi katabolik (antara lain bergerak). Kadar protein pada daging, telur, kulit dan gelembung renang ikan tuna dapat dilihat pada Gambar 3. 


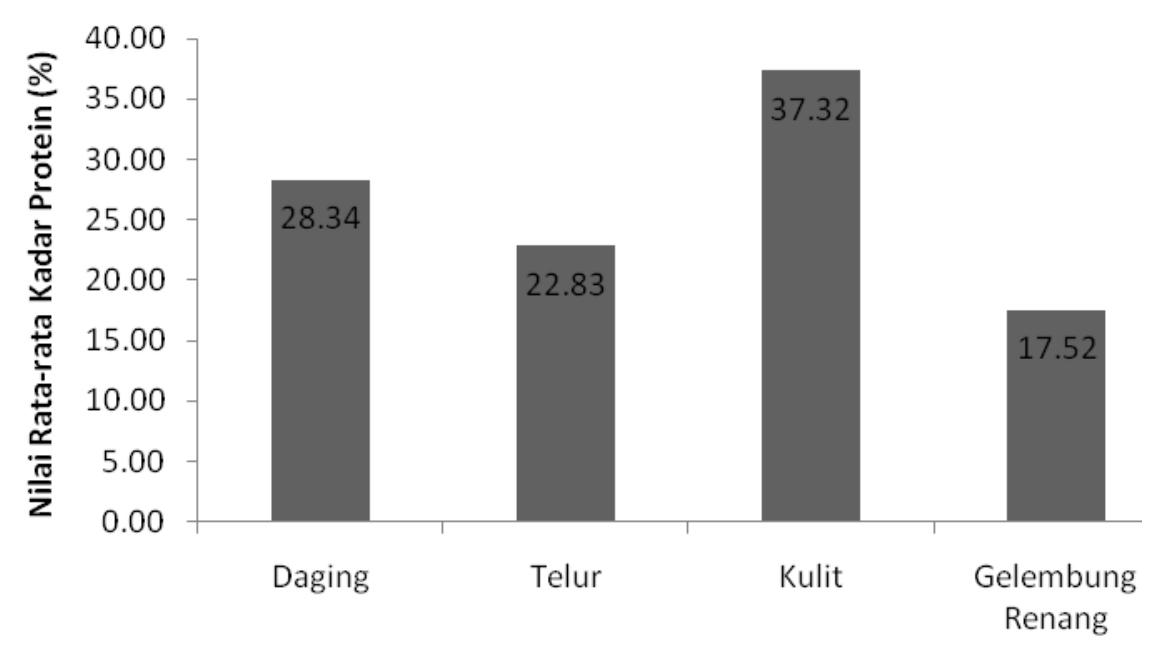

Bagian Tubuh Ikan Tuna

Gambar 3. Nilai Rata-Rata Kadar Protein pada Bagian Tubuh Ikan Tuna

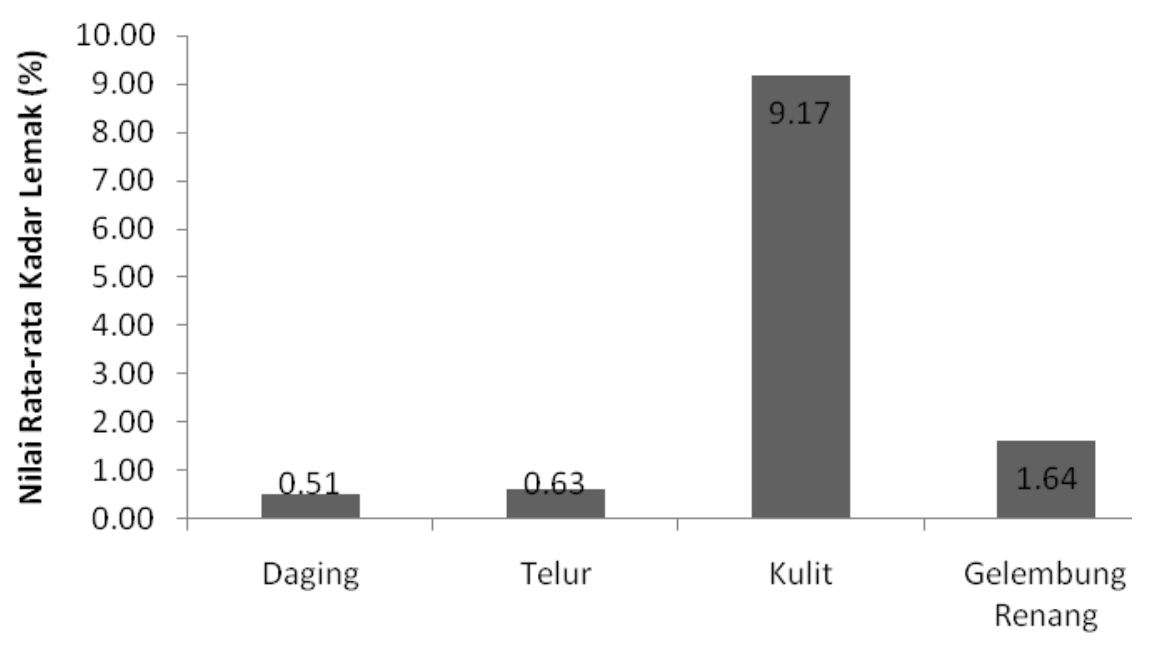

Bagian Tubuh Ikan Tuna

Gambar 4. Nilai Rata-Rata Kadar Lemak pada Bagian Tubuh Ikan Tuna

Pada Gambar 3 dapat dilihat bahwa kandungan protein terbesar terdapat pada bagian kulit ikan tuna sebesar $37,32 \%$, kemudian pada daging $28,34 \%$, pada bagian telur $22,83 \%$ dan kandungan protein terkecil terdapat pada bagian gelembung renang sebesar $17,52 \%$.

Pada bagian daging ikan tuna mengandung protein sebesar 28,34\%, Sementara hasil penelitian Wahyuni (2011) dan Wellyalina (2013) menunjukkan hasil yang lebih rendah, yaitu $23,2 \%$ dan $20,64 \%$.

Kandungan protein pada telur ikan tuna sebesar 22,83\%, nilai ini lebih tinggi dibandingkan pada telur ikan cakalang, yaitu sebesar 19,81\% (Rieuwpassa et al, 2013) dan lebih rendah dibandingkan telur ikan terbang 47,95\% (Azka et al, 2015).

Kulit ikan tuna mengandung protein $37,32 \%$, nilai ini lebih tinggi jika dibandingkan hasil penelitian Nurilmala et al, (2017) dan Hema et al, (2013) yaitu $36,45 \%$ dan $20,54 \%$.

Gelembung renang ikan tuna mengandung protein sebesar $17,52 \%$, lebih tinggi jika dibandingkan hasil penelitian Kaewdang et al, (2014) yaitu 12,09\%, gelembung renang ikan cunang mengandung protein sebesar 33,67\% (Gadi et al., 2017).

Komposisi gizi ikan tuna bervariasi tergantung spesies, jenis, umur, musim, laju metabolisme, aktivitas pergerakan, dan tingkat kematangan gonad (Wahyuni 2011). Buckle et al. (1987) menyatakan bahwa kadar protein ikan dipengaruhi oleh kadar air dan kadar lemak, bahwa terdapat hubungan terbalik antara protein dan kadar air pada bagian yang dapat dimakan. Semakin tinggi kadar protein maka akan semakin rendah kadar airnya. 


\section{Kadar Lemak}

Lemak adalah bentuk energi berlebih yang disimpan oleh hewan sehingga jumlah lemak dalam hewan yang dijadikan bahan pangan ditentukan oleh keseimbangan energi hewan tersebut. Lemak juga dapat digunakan sebagai sumber asam lemak esensial dan vitamin (vitamin A, D, E dan K) (Belitz et al. 2009). Hasil pengukuran kadar lemak pada bagian tubuh ikan tuna dapat dilihat pada Gambar 4.

Gambar 4 menunjukkan nilai rata-rata kadar lemak pada bagian tubuh ikan tuna berurutan, pada daging, telur, kulit dan gelembung renang yaitu $0,51 \%, 0,63 \%, 9,17 \%$ dan $1,64 \%$.

Pada bagian daging ikan tuna mengandung kadar lemak $0,51 \%$. Sementara hasil penelitian Wahyuni (2011) dan Wellyalina (2013) menunjukkan hasil yang lebih tinggi, yaitu $<5 \%$ dan $1,6 \%$.

Kandungan lemak pada telur ikan tuna $0,63 \%$, nilai ini setara dengan kadar lemak pada telur ikan terbang yang diteliti oleh Azka et al. (2015), yaitu $0,63 \%$. Sedangkan berdasarkan penelitian Rieuwpassa et al (2013), ikan cakalang mengandung lemak sebesar 3,41\%.

Gelembung renang ikan tuna mengandung lemak 1,64\%, sedangkan kandungan lemak pada gelembung renang ikan tuna yang diteliti oleh Kaewdang et al. (2014) tidak terpaut jauh, yaitu sebesar 1,44\%. Gelembung renang ikan cunang yang diteliti Gadi et al (2017) mengandung lemak yang lebih rendah, yaitu $0,31 \%$.

\section{KESIMPULAN}

Dari penelitian yang telah dilakukan diperoleh kesimpulan bahwa selain daging, bagian tubuh ikan tuna yang lain juga memiliki potensi gizi yang baik. Kulit ikan tuna mengandung protein yang lebih banyak dibandingkan dengan daging.

\section{SARAN}

Perlu dilakukan penelitian lanjutan untuk mengetahui komposisi gizi pada bagian tubuh yang lain pada ikan tuna seperti pada mata, insang dan sirip.

\section{DAFTAR PUSTAKA}

Abun, Rusmana D, Saefulhadjar D. 2004. Pengaruh Cara Pengolahan Limbah Ikan Tuna (Thunnus atlanticus) Terhadap Kandungan Gizi dan Nilai Energi Metabolisme Ayam Pedaging. Laporan Penelitian. Universitas Padjadjaran.
Azka A, Nurjanah, Jacoeb AM. 2015. Profil Asam Amino, Asam Lemak, Total Karotenoid dan a Tokoferol Telur Ikan Terbang. Jurnal Pengolahan Hasil Perikanan Indonesia 18(3): 250-261.

[BPS] Badan Pusat Statistik Provinsi Maluku. 2017. Maluku Dalam Angka. BPS Provinsi Maluku.

Belitz HD, Grosch W, Schieberle P. 2009. Food Chemistry. Ed rev ke-4. Verlag: Springer.

Buckle KA, dkk. 2004. Ilmu Pangan. Penerjemah: Hari Purnomo dan Adiono. UI Press. Jakarta.

Fauzi RL. 2014. Pembuatan Biodiesel Dari Jeroan Tuna Sirip Kuning Menggunakan Katalis $\mathrm{CaO}$ Dengan Metode Transesterifikasi Bertingkat. [Skripsi]. Teknologi Hasil Perikanan Universitas Gadjah Madah. Jogjakarta.

Gadi DS, Trilaksani W, Nurhayati T. 2017. Histologi, Ekstraksi dan Karakterisasi Kolagen Gelembung Renang Ikan Cunang (Muarenesox talabon). Jurnal IImu dan Teknologi Kelautan Laut Tropis 9(2): 665683.

Hema GS, Shyni K, Mathew S, Anandan R, Ninan G. 2013. A simple method for isolation of fish skin collagen- biochemical characterization of skin collgagen extracted from Albacore Tuna (Thunnus alalunga), Dog Shark (Scoliodon sorrakowah), and Rohu (Labeo rohita). Annals of Biological Research. 4(1): 271278.

llyas. 1983. Teknologi Refrigerasi Hasil Perikanan. CV. Paripurna. Jakarta.

Irianto HE, Giyatmi S. 2009. Prinsip Dasar Teknologi Pengolahan Hasil Perikanan. Penerbit Universitas Terbuka. Jakarta.

Kaewdang O, Benjakul S, Kaewmanee T, Kishimura H. 2014. Characteristics of Collagens From the Swim Bladders of Yellowfin Tuna (Thunnus albacares). Food Chemistry 155: 264-270.

[KKP] Kementerian Kelautan dan Perikanan. 2007. Indonesian Fisheries Statistics Index 2006. Kementerian Kelautan dan Perikanan. Jakarta.

Nurilmala M, Jacoeb AM, Dzaky RA. 2017. Karakteristik Gelatin Kulit Ikan Tuna Sirip Kuning. Jurnal Pengolahan Hasil Perikanan Indonesia 20(2): 339-350.

Pangke RB, Lohoo HJ, Agustin AT. 2016. Ekstraksi Gelatin Kulit Ikan Tuna Dengan Proses Basa $(\mathrm{NaOH})$. Jurnal Media Teknologi Hasil Perikanan 4(2): 92-94.

Rieuwpassa FJ, Santoso J, Trilaksani W. 2013. Karakteristik Sifat Fungsional Konsentrat Protein Telur Ikan Cakalang (Katsuwonus 
pelamis). Jurnal Ilmu dan Teknologi Kelautan Tropis 5(2): 299-309.

Sahubawa L. 2012. Valuasi Ekonomi Sumber daya Alam dan Lingkungan Hidup. Materi Ajar Ekonomi Lingkungan Edisi Maret 2012. Program Magister Pengelolaan Lingkungan, Sekolah Pascasarjana UGM Yogyakarta.

Silva TM, Sabaini PS, Evangelista WP, Gloria MBA. 2010. Occurrence of Histamine in Brazilian Fresh and Canned Tuna. Food Control 22(2):323- 327.

Stansby ME, Olcott HS. 1963. Composition of Fish. Di dalam: Stansby ME, Dassow JA, editor. Industrial Fishery Technology. London: Reinhold Publishing Co. Chapman and Hall Ltd.

Sudarmadji S, dkk. 2007. Prosedur Analisis Untuk Bahan Makan Dan Pertanian. Liberty. Yogyakarta

Sugiono. 2007. Ilmu Pengetahuan Bahan Pangan. Institut Pertanian Bogor. Bogor.

Tejasari. 2005. Nilai Gizi Pangan. Graha Ilmu. Yogyakarta.

Trilaksani W, Salamah E, Nabil M. 2006. Pemanfaatan Limbah Tulang Ikan Tuna (Thunnus sp.) Sebagai Sumber Kalsium Dengan Metode Hidrolisis Protein. Buletin Teknologi Hasil Perikanan 9(2): 34-45.

Wahyu DS, Dwi TS, Eddy S. 2013. Pemanfaatan Residu Daging Ikan Gabus (Ophiocephalus striatus) Dalam Pembuatan Kerupuk Beralbumin. THPI Student Journal 1(1): 21-32.

Wahyuni S. 2011. Histamin Tuna (Thunnus sp.) dan Identifikasi Bakteri Pembentuknya Pada Kondisi Suhu Penyimpanan Standar. [Skripsi]. Bogor: Teknologi Hasi Perikanan IPB.

Wellyalina, Azima F, Aisman. 2013. Pengaruh perbandingan tetelan tuna dan tepung maizena terhadap mutu nugget. Jurnal Aplikasi Teknologi Pangan 2(1): 9-17.

Winarno FG. 2008. Kimia Pangan dan Gizi. PT Gramedia Pustaka Utama. Jakarta. 